\title{
Nurse Compliance using Basic Personal Protective Equipment in Providing Health Services Nursing Actions
}

\author{
Suprapto Suprapto
}

\section{Suprapto Suprapto Department Nursing of Academy Politeknik Sandi Karsa, Makassar, South Sulawesi, INDONESIA.}

\section{Correspondence}

Mr. Suprapto Suprapto

Department Nursing of Academy Politeknik Sandi Karsa, Bung Number 37 Makassar, South Sulawesi, INDONESIA. Mobile no: +62 081242800025

Email: atoenurse@gmail.com

\section{History}

- Submission Date: 18-05-2020

- Revised Date: 24-06-2020

- Accepted Date: 16-07-2020

DOI : 10.5530/ijmedph.2020.3.25

Article Available online

http://www.ijmedph.org/v10/i3

\section{Copyright}

(C) 2020 Phcog.Net. This is an openaccess article distributed under the terms of the Creative Commons Attribution 4.0 International license.

\begin{abstract}
Background: Personal protective equipment is a tool used by a person in his work that is intended to protect himself from certain sources of danger both from work and the work environment and is useful in reducing or preventing disability. Objectives: This needs serious attention by examining nurses' compliance in using Personal Protective Equipment when providing nursing services to reduce the incidence of nosocomial infections and work disabilities. Methods: This research was conducted by a descriptive method, sample selection with total sampling. The number of samples studied was 40 respondents. Data were collected from patients using the nurse's compliance questionnaire in using hands-on personal protective equipment and masks as well as observing nurses' compliance in using hands-on personal protective equipment and masks as well as the availability of supplies of personal protective equipment in the emergency room. Results: Nurse Compliance research in using personal protective equipment in the emergency room is a maximum of $85 \%$ and there are still $15 \%$ non-adherents and the supply of equipment for personal protective equipment in the emergency room is still limited, especially for personal protective equipment mask. Conclusion: Influenced by the respondent's age, last education and length of work and availability of personal protective equipment. It is expected that the parties pay attention to their employees in their compliance with personal protective equipment while working and facilitate the availability of personal protective equipment in each room, especially in emergency rooms that serve a large number of patients in a day.

Key words: Compliance, Personal Protective Equipment, Nurse.
\end{abstract}

\section{INTRODUCTION}

Control methods can be done to reduce hazards in the work environment where the best way is to eliminate the hazard or close the source of the danger, if possible but often these dangers cannot be completely controlled and therefore efforts are needed to prevent them by using some personal protective equipment. ${ }^{1}$ Personal protective equipment is a tool that is used by someone in their work which is intended to protect themselves from certain sources of danger both from work and the work environment and is useful in reducing or preventing disability, there are some nurses who do not obediently wear gloves and masks when going give action to the patient, the nurse wears gloves that do not match the size and wears gloves that are not sterile. Nurses assume not all actions must wear gloves and masks. These results indicate that nurses' compliance in wearing personal protective equipment is not compliant. ${ }^{2}$

The results showed statistical results at a significant level $\alpha<0.05$ obtained there was a strong relationship between knowledge of nurses with compliance using personal protective equipment according to SOP ( $\rho$ value $=0.024)$, there was a significant relationship between nurses' attitudes with adherence using appropriate personal protective equipment SOP ( $\rho$ value $=0.027)$ and there is no meaningful difference between nurses' actions and compliance using personal protective equipment according to SOP ( $\rho$ value $=0.100)$, in the BLUD inpatient room of Konawa Regency Hospital in 2015. ${ }^{3}$ Based on the simultaneous test is $84.1 \%$, it is very strong that surgical nurse compliance is really real/significantly influenced by behavioral factors that are variables in this study, namely: attitude, length of work, supervision, availability of PPE, peers, perception and only 15 , Only $9 \%$ of other factors outside the variables used in this study could affect nurses' compliance in using PPE in IBS Ulin Hospital Banjarmasin. Banjarmasin. ${ }^{4}$

Obedience is like obeying orders, obeying orders or rules. Whereas obedience is behavior according to the rules and discipline. The work of operators in the Coal Yard is a job that requires expertise, creativity and a high concentration in doing work because the workplace is exposed to a lot of coal dust, besides the means of personal protective equipment (PPE) is an important component in reducing the exposure of coal dust to operator worker. ${ }^{5}$ The factors that influence the enabling factors are the lack of means of supporting PPE, SOPs are not yet available about PPE, while the reinforcing factor is due to the lack of socialization about PPE, oversight that is still lacking,

Cite this article: Suprapto S. Nurse Compliance Using Basic Personal Protective Equipment in Providing Health Services Nursing Actions. Int J Med Public Health. 2020;10(3):119-21. 
there are no sanctions or rewards for those who obey or are not compliant to use PPE. Health status is influenced by predisposing factors, enabling factors, reinforcing factors and compliance with PPE use by $45.7 \%$ while $54.3 \%$ is influenced by other variables. ${ }^{6}$

Preparation of fixed procedures or operational standard procedures governing personal protective equipment in hospitals, will reduce the risk of a nurse being infected by the disease so that the safety of nurses' work will be more secure and the provision of nursing care will be of better quality because it is carried out according to existing operational standards. Each hospital certainly has a standard operational procedure of action that must be followed by every health worker, but there are still health workers who do not use basic personal protective equipment.

\section{MATERIALS AND METHODS}

The research design used is descriptive design. This study aims to identify nurses' compliance in using personal protective equipment in the emergency room at the Makassar General Hospital. In particular, it also wants to know how nurses' habits in using personal protective equipment in providing nursing care services. Research with a descriptive design aims to describe (describe) urgent events that occur in the current conditions. Descriptive activity is carried out systematically and emphasizes more on factual data than the conclusion.

The population in this study were all nurses in the emergency room with a total of 40 people. The sample is a portion of the whole object examined which is considered to represent the entire population. In this study the sample was all nurses who served in the emergency unit. Determination of the number of samples using total sampling techniques how to take this sample is to take all members of the population into the sample because of limited population.

Multivariate analysis was carried out to explain or describe the characteristics of the observed variables and measured based on the value of data distribution, namely the minimum and maximum values. The variables studied in the questionnaire were Nurse's compliance in using (handscon and mask) and also to know the age, sex and duration of work. Personal protective equipment in the emergency room.

\section{RESULTS AND DISCUSSION}

Based on the analysis shows that of the 40 respondents, the majority complied with the use of basic personal protective equipment handson and masks with a total of $34(85 \%)$ and respondents who were not compliant in the use of basic personal protective equipment hands-on and masks when performing nursing actions amounted to 6 people (15\%). The level of compliance of nurses in using personal protective equipment on duty in the emergency room can be categorized as compliant to the maximum (85\%). But in this study there were still respondents who were not compliant in the use of personal protective equipment there were $6(15 \%)$ respondents with various reasons.

Expressing compliance can be influenced by internal factors and external factors such as age, education, knowledge and years of service which suggests that the factors that affect compliance are education, age and length of work. ${ }^{7}$ That the majority of nurses in PKU Muhammadiyah Gombong Hospital have a good level of knowledge (88.3\%). The majority of nurses at PKU Muhammadiyah Gombong Hospital have compliant behavior in the use of personal protective equipment (78.3\%). There is a relationship between the level of knowledge of nurses with the level of compliance of nurses in the use of personal protective equipment for the prevention and reduction of risk of infection in PKU Muhammadiyah Gombong Hospital $(p=0,000){ }^{8}$

It can be concluded starting in terms of the age of the respondents 20-29 years (45\%), 30-39 years (45\%) and 40-49 years (10\%) also affect one's compliance. That someone in old age is more adaptive so that in carrying out a procedure more quickly respond and do it correctly. ${ }^{9}$ Inversely proportional to those stating that someone who is younger tends to have a strong physique and can work hard but in working less disciplined and less responsible. ${ }^{10}$

The results of hypothesis testing using the Chi-square test between the age variable and the nurse's compliance variable to the use of PPE showed a $p$-value of $0.779>0.05$, which means that Ha was refused H0. So it can be concluded that there is no relationship between the age of the respondents with the level of compliance of respondents in using PPE. ${ }^{11}$

Respondent education is also a factor that influences the compliance of nurses with DIII nursing education as many as 14 (35\%), Nursing S1 as much as $20(50 \%)$ and Nurse education $6(15 \%)$, where education influences the individual mindset while the mindset influences one's behavior as well as will. Willingness is a basic impulse from within that is higher than instinct, reflexes, automatism, craving, habits, inclinations and passions. Willingness is the encouragement of the conscious mind based on consideration of thoughts and feelings and the whole person who causes activities directed at achieving certain goals related to the needs of his personal life. ${ }^{12}$ This is perhaps what the nurses lacked. Although the level of knowledge is good because of the high level of education, but if there is no will they will not be obedient to use personal protective equipment. ${ }^{13}$ In accordance with the statistical test results a significant value $(\rho)=0.296$ where this value is greater than the value used which is $\alpha=0.05$. Conclusion: there is no significant relationship between the education level of emergency nurse nurses with compliance with the implementation of standard operating procedures for admission of new patients in AM Parikesit Tenggarong Hospital. ${ }^{14}$

Length of work $>5$ years (55\%), $5-10$ years $(40 \%)$ and $<10$ years $(5 \%)$ are also factors that influence compliance. According to Gibson (1997), the longer a person works the higher the level of achievement, the high achievement comes from good behavior in this case good behavior to use personal protective equipment while working.

Where someone who has worked for a long time is expected to better understand his work including the effects of his work. Supervision is the variable that contributes the most in influencing nurses in using personal protective equipment in the prevention of nosocomial infections in hospitals. Range It is recommended that the hospital be obliged to facilitate, complete the means of personal protective equipment in accordance with health and safety regulations and laws and is expected

Table 1: Multivariate Tests.

\begin{tabular}{ccccccc}
\hline \multirow{2}{*}{ Obedient } & Value & $F$ & $\begin{array}{c}\text { Hypothesis } \\
\mathbf{d}_{f}\end{array}$ & $\mathbf{d}_{f}$ & Sig. \\
\cline { 3 - 7 } Obedient & Pillai's Trace & .965 & $247.246 \mathrm{~b}$ & 4.000 & 36.000 & .000 \\
& Wilks' Lambda & .035 & $247.246 \mathrm{~b}$ & 4.000 & 36.000 & .000 \\
& Hotelling's Trace & 27.472 & $247.246 \mathrm{~b}$ & 4.000 & 36.000 & .000 \\
& Roy's Largest Root & 27.472 & $247.246 \mathrm{~b}$ & 4.000 & 36.000 & .000
\end{tabular}


to the party hospitals, especially leaders or related officers must carry out inspection, inspection, control and various actions in supervision of the use of personal protective equipment. And it is expected to the hospital to give strict sanctions and awards to nurses to be motivated to wear personal protective equipment. ${ }^{15}$ There is no relationship between the length of work of nurses with the attitude of compliance with SPO with the result $p$ value $=0.943$. The conclusion of the study there is no meaningful relationship between length of work with compliance, it is recommended that the hospital create a program that is able to make nurses adhere like supervision and performance evaluation which is more structured. ${ }^{16}$

The longer a person works, the more skilled and more experienced in carrying out work. The performance meant performance in carrying out nursing care of course all nursing actions that have been prepared in accordance with nursing standards issued by the Ministry of Health and Agencies in the form of standard operating procedures, as a manifestation of the professional attitude of nursing care of the Ministry of Health of the Republic of Indonesia has imposed the existence of standard operating procedures (SOP). ${ }^{17}$ Therefore compliance from the use of personal protective equipment is influenced by several factors, namely the age of the nurse, the last education and also the length of work that affects someone's compliance, it is expected that the implementing nurse so that in performing nursing actions do it according to the SOP which includes the use of protective equipment yourself at work and this may be an important study for hospital management in the emergency room so that in the future it can be known what exactly is the root of the problem there are still nurses who are not compliant in using personal protective equipment handscoon and masks so that solutions can be found to overcome them in the hope that these nurses can be motivated to always work according to standards including being motivated to always use handscon personal protective equipment and masks when performing nursing actions. To reduce the incidence of nosocomial infections and transmission of disease from patients to our bodies to keep ourselves safe at work (Table 1).

\section{CONCLUSION}

Based on research conducted at the Hospital of the emergency room unit, it can be concluded that: The level of compliance of nurses in using basic handcoon protective equipment and masks, is at a maximum level of $85 \%$, only a small proportion of non-compliant $15 \%$ and the availability of basic personal protective equipment handscon masks in the emergency room are quite limited, especially masks with a very limited amount in a day.

To reduce the incidence of nosocomial infections and disease transmission from patients to our body and also to the responsible party of the hospital, especially for the emergency room to pay attention and give a warning if there are nursing nurses who bypass nursing procedures including in the use of personal protective equipment for the emergency room to be firm in overseeing the discipline of its employees so as to create a structured work environment and work according to standard operating procedures.

\section{ACKNOWLEDGEMENT}

Appreciation was directed at the Makassar Indonesian Academy of Nursing, Sandi Karsa, which allowed this paper to be produced. This paper is also under the terms of the Short-Term Grant (005 / LPPM / AKPER-SK by the Institute for Research and Service of the Academy of Keperawata Sandi Karsa Makassar Indonesia.

\section{CONFLICT OF INTEREST}

There are no conflicts of interest

\section{REFERENCES}

1. Putri KDS, Yustinus DAW. Analysis of factors related to compliance using personal protective equipment. The Indonesian Journal of Occupational Safety, Health and Environment. 2014;1(1):24-36.

2. Arifianto $A$, Arifin MT, Widyastuti $\mathrm{RH}$. Nurse Compliance in Implementing Patient Safety Targets for Infection Risk Reduction by using Personal Protective Equipment at Home. Diponegoro University. 2017.

3. Banda I. Relationship between Nurse Behavior and Compliance Using Personal Protective Equipment (PPE) According to Standard Operating Procedure (SOP) in the Inpatient Room of the Regional Public Service Agency (BLUD) Konawe Hospital in 2015 (thesis). Kendari: Universitas Haluoleo. 2015.

4. Sudarmo S, Helmi ZN, Marlinae L. Factors Affecting Behavior Towards Compliance Use of Personal Protective Equipment (APD) for the Prevention of Occupational Diseases. Jurnal Berkala Kesehatan. 2017;1(2):88-95.

5. Arifin AB. Factors Related to Worker's Compliance in the use of Personal Protective Equipment (PPE) in the Coal Yard Section of PT X Units 3 and 4 of 2012. Diponegoro University. 2013.

6. Liswanti Y. Factors Related to Compliance with the Use of Personal Protective Equipment (PPE) and Its Relationship to the Health Status of Household Garbage Collection Officers in Tasikmalaya City in 2014. Jurnal Kesehatan Bakti Tunas Husada: Jurnal IImu-ilmu Keperawatan, Analis Kesehatan dan Farmasi. 2015;13(1).

7. Suardana IK, Susanti NNT. Performance Monitoring in Improving Nurse Compliance in Implementing Standard Operating Procedures. Faktor Penyebab Rendahnya Jumlah Pria Menjadi Akseptor Keluarga Berencana. 2010;78.

8. Mardiana DR. The Relationship between Nurse Knowledge Level and Nurse Compliance Level in Using Personal Protective Equipment for the Prevention and Reduction of Infection Risk in Pku Muhammadiyah Hospital Gombong. Stikes Muhammadiyah Gombong. 2017.

9. Suprapto. Description of Nurse Compliance in the use of Basic Personal Protective Equipment (Handscoons and Masks) in the Emergency Room of the Pangkep Regional General Hospital. Jurnal IImiah Kesehatan Sandi Husada. 2016;6(2):1-10.

10. Prihantoro A. Improving Human Resource Performance Through Motivation, Discipline, Work Environment and Commitment. Deepublish. 2015.

11. Putri SA, Widjanarko B, Shaluhiyah Z. Factors Related to the Nurse's Compliance Level with the use of Personal Protective Equipment (APD) at Dr. RS. Kariadi Semarang (Case Study in the Peacock Inpatient Installation). Jurnal Kesehatan Masyarakat. 2018;6(1):800-8.

12. Prawira GED. The Efforts of the Bojonegoro Regency Revenue Service in Increasing Local Revenue (PAD) from the Entertainment Tax Sector: Study at the Bojonegoro Regency Revenue Service. Universitas Brawijaya. 2010.

13. Asmadi BBB. The Effect of Learning Discipline and Family Environment on Mathematics Learning Outcomes Class V Sdn Cluster Ki Hajar Dewantara Mijen Semarang. Universitas Negeri Semarang. 2017.

14. Fahkrur AA. The Relationship between the Education Level of Emergency Care Nurses and Compliance with the Implementation of Standard Operating Procedures for Accepting New Patients in AM Parikesit Tenggarong Hospital. Jurnal IImu Kesehatan. 2017;5(1):1-10.

15. Siagian J. Effects of Supervision and Compliance on the use of Personal Protective Equipment in Nurses in the Prevention of Nosocomial Infection in the Regional General Hospital. 2013.

16. Hakim AR, Manurung I, Yuniastini Y. Nurse's Working Length Difference With Compliance To Standard Operating Procedures. Jurnal Ilmiah Keperawatan Sai Betik. 2017;10(2):246-50.

17. Moniung F, Rompas S, Lolong J. The long-standing relationship with nurses' compliance in carrying out SOP for infusion installation in GMIM General Hospital emanating love Manado. Jurnal Keperawatan. 2016;4(2). 